\title{
Molecular background of cadmium tolerance in Rht dwarf wheat mutant is related to a metabolic shift from proline and polyamine to phytochelatin synthesis
}

\author{
Gabriella Szalai ${ }^{1} \cdot$ Judit Tajti $^{1} \cdot$ Kamirán Áron Hamow $^{1} \cdot$ Denyicska lldikó $^{1} \cdot$ Radwan Khalil $^{2} \cdot$ Radomira Vanková $^{3}$. \\ Petr Dobrev $^{3}$ - Svetlana P. Misheva ${ }^{4} \cdot$ Tibor Janda $^{1} \cdot$ Magda Pál $^{1}$
}

Received: 5 November 2019 / Accepted: 30 March 2020 / Published online: 15 April 2020

(C) The Author(s) 2020

\begin{abstract}
Plant height is among the most important agronomic traits influencing crop yield. Wheat lines carrying Rht genes are important in plant breeding due to their both higher yield capacity and better tolerance to certain environmental stresses. However, the effects of dwarf-inducing genes on stress acclimation mechanisms are still poorly understood. Under the present conditions, cadmium stress induced different stress responses and defence mechanisms in the wild-type and dwarf mutant, and the mutant with the Rht$B 1 c$ allele exhibited higher tolerance. In the wild type after cadmium treatment, the abscisic acid synthesis increased in the leaves, which in turn might have induced the polyamine and proline metabolisms in the roots. However, in the mutant line, the slight increment in the leaf abscisic acid content accompanied by relatively high salicylic acid accumulation was not sufficient to induce such a great accumulation of proline and putrescine. Although changes in proline and polyamines, especially putrescine, showed similar patterns, the accumulation of these compounds was antagonistically related to the phytochelatin synthesis in the roots of the wild type after cadmium stress. In the dwarf genotype, a favourable metabolic shift from the synthesis of polyamine and proline to that of phytochelatin was responsible for the higher cadmium tolerance observed.
\end{abstract}

Keywords ABA $\cdot \mathrm{PCs} \cdot \mathrm{PA} \cdot$ Proline $\cdot \mathrm{Rht} \cdot \mathrm{SA}$

$\begin{array}{ll}\text { Abbreviations } \\ \text { ABA } & \text { Abscisic acid } \\ \text { DAP } & \text { 1,3-Diaminopropane } \\ \text { GAs } & \text { Gibberellins } \\ \text { ICS } & \text { Isochorismate synthase } \\ \text { MDA } & \text { Malondialdehyde } \\ \text { NCED } & \text { 9-cis-Epoxycarotenoid dioxygenase } \\ \text { OAT } & \text { Ornithine aminotransferase }\end{array}$

Responsible editor: Gangrong Shi

Magda Pál

pal.magda@agrar.mta.hu

1 Centre for Agricultural Research, 2462, Martonvásár H-2462, Hungary

2 Faculty of Science, Benha University, Benha 13518, Egypt

3 Institute of Experimental Botany of the Czech Academy of Sciences, 16502 Prague, Czech Republic

4 Institute of Plant Physiology and Genetics, Bulgarian Academy of Sciences, 1113 Sofia, Bulgaria
P5CS $\quad \Delta^{1}$-Pyrroline-5-carboxylate synthase

PC Phytochelatin

PCS Phytochelatin synthase

PUT Putrescine

SA Salicylic acid

SPD Spermidine

SPM Spermine

\section{Introduction}

Cadmium is one of the major toxic metal pollutants, influencing and inhibiting several physiological and biochemical processes (Sanita di Toppi and Gabbrielli 1999). However, plants have evolved several defence mechanisms to minimise the damage caused by exposure to non-essential metal ions (DalCorso et al. 2008). The nitrate and sulphate assimilation pathways activated shortly after exposure to heavy metal play an important role in the increase in phytochelatin (PC) accumulation (Astolfi et al. 2004). These small molecule weight peptides are synthesised from glutathione in a reaction 
catalysed by phytochelatin synthase (PCS) and are capable of chelating metal ions in order to detoxify them via vacuolar compartmentalisation (Pál et al. 2006, 2018a). Other defence mechanisms involve the synthesis of protective compounds, such as proline or polyamines (PAs) (Balestrasse et al. 2005), and stress signalling molecules, such as salicylic acid (SA) (Kovács et al. 2014), abscisic acid (ABA) (Tran and Popova 2013) or gibberellins (GAs) (Zhu et al. 2012).

It has been revealed that the wheat dwarf mutant line Rht$B 1 c$ is more tolerant to drought and Cd stress than the tall wild-type line Rht-B1a (Kocheva et al. 2014a, b; Nenova et al. 2014; Dobrikova et al. 2017). The wild allele $-B 1 a$ at locus Rht-Bl encodes for DELLA proteins, which act as transcriptional repressors of the GA signalling pathway and retard plant growth (Achard and Genschik 2009). The mutant allele $-B 1 c$ at the same locus (formerly designated as the $R h t 3$ gene) encodes for aberrant DELLA proteins that are unable to interact with the GA receptor, resulting in reduced GA responsiveness (Wen et al. 2013). The better stress tolerance of the Rht$B 1 c$ line has been related to alterations of the photosynthetic membranes, the increased capacity of the photosystem I cyclic electron transport, the accumulation of osmoprotectants and the higher activity of certain antioxidant enzymes (Dobrikova et al. 2017). However, the effects of wheat dwarfing genes, encoding modified DELLA proteins, on stress acclimation mechanisms are still poorly understood, as is the role of GAs under Cd stress (Asgher et al. 2014). Although Cd, Cu and $\mathrm{Zn}$ treatments have been reported to increase the level of $\mathrm{GA}_{3}$ in the roots of Arabidopsis plants, this increment was not related with the induction of glutathione or PC synthesis (Sofo et al. 2013). Thus, interactions between GA signalling and PC synthesis still need further research.

Apart from their direct protective effects, PAs also act as signalling molecules, with a role in the regulation of stress tolerance, and are involved both in direct interactions with a number of metabolic routes and in hormonal crosstalk (Pál et al. 2015). Transgenic Arabidopsis plants that constitutively overexpress the gene encoding arginine decarboxylase, which is responsible for the synthesis of the diamine PA putrescine (PUT), exhibited a reduction in both the amounts of $\mathrm{GA}_{1}$, $\mathrm{GA}_{4}$ and $\mathrm{GA}_{9}$, and in the transcript levels of AtGA20oxl, AtGA3oxl and AtGA3ox3 (Alcázar et al. 2005), suggesting that PUT accumulation represses GA synthesis. Recent results showed that the Rht-B1c mutation responsible for the dwarf phenotype may also affect the PA metabolism in wheat plants (Pál et al. 2019).

Accordingly, the objective of the present study was to reveal the role of the mutant DELLA-encoding gene in Cd tolerance. Little information is available on the relationship between plant growth regulators, such as plant hormones or PAs, and PC synthesis under Cd stress. The responses of the dwarf mutant have not yet been compared with those of the wild type. Very few studies have been done on the relationship between GA and SA, a plant hormone playing a role in stress responses (Navarro et al. 2008; Alonso-Ramírez et al. 2009; Gallego-Giraldo et al. 2011). Thus, this study focused on elucidating the relationship between PC synthesis and changes in the PA metabolism and in SA and ABA synthesis after $\mathrm{Cd}$ exposure in plants carrying the wild allele Rht-Bla and in dwarf plants with the Rht-B1c allele.

\section{Materials and methods}

\section{Plant materials, growth conditions and treatments}

Near-isogenic lines of the wheat (Triticum aestivum L.) variety 'April Bearded': a dwarf line carrying the mutant allele $R h t-B 1 c$ (formerly Rht3) and a tall counterpart, carrying the wild-type allele Rht-Bla (WT) were used in this study (Flintham et al. 1997). The improved Cd tolerance of this dwarf line compared with the wild type was manifested as better photosynthetic activity (Dobrikova et al. 2017).

After germination for 3 days at $26{ }^{\circ} \mathrm{C}$ in the dark, wheat seedlings (15/beaker) were grown in modified Hoagland solution in a Conviron GB-48 plant growth chamber (Controlled Environments Ltd., Winnipeg, Canada) according to as it was described by Pál et al. (2019). After 10 days of growth under normal conditions, half of the seedlings were treated with $50 \mu \mathrm{M} \mathrm{Cd}\left(\mathrm{NO}_{3}\right)_{2}$ in a hydroponic system for 7 days. Leaves and roots of the plants were collected from control and Cdtreated wheat plants for biochemical and gene expression studies on the 7th day of the $\mathrm{Cd}$ treatment.

\section{Determination of cadmium and proline contents and lipid peroxidation}

The Cd content was determined using the inductively coupled plasma-atomic emission spectrometry method (ICP-AES, Jobin-Yvon Ultima 2 sequential instrument) (Anton et al. 2012). The proline content was measured according to Bates et al. (1973) as the absorbance at $520 \mathrm{~nm}$ using a spectrophotometer. The detection of lipid peroxidation was based on the determination of malondialdehyde (MDA) at $532 \mathrm{~nm}$ after subtracting the non-specific absorption at $600 \mathrm{~nm}$, using an extinction coefficient of $155 \mathrm{mM}^{-1} \mathrm{~cm}^{-1}$ (Thomas et al. 2004).

\section{Determination of phytochelatin content and phytochelatin synthase activity}

The in vivo PC contents and in vitro PCS activity (PCS: EC:2.3.2.15) were analysed by HPLC according to Chen et al. (1997), as modified by Szalai et al. (2013). Root or leaf samples weighing $750 \mathrm{mg}$ were ground with $750 \mu \mathrm{l}$ of extraction buffer consisting of $50 \mathrm{mM}$ Tris- $\mathrm{HCl}$ buffer, $\mathrm{pH} 8.0$; 
$10 \mathrm{mM} \beta$-mercaptoethanol ( $\beta \mathrm{ME}) ; 1 \mathrm{mM}$ phenylmethylsulfonyl fluoride; and $14 \%(v / v)$ glycerol. After centrifugation for $10 \mathrm{~min}$ at $10,000 \times \mathrm{g}$, the supernatant was used for the standard assay. The mixture for PCS contained $200 \mu \mathrm{l}$ of the supernatant, $25 \mu \mathrm{l}$ of $2.4 \mathrm{M}$ Tris- $\mathrm{HCl}$ buffer (pH 8.0), $25 \mu \mathrm{l}$ of $6 \mathrm{mM} \mathrm{Cd}\left(\mathrm{NO}_{3}\right)_{2}, 25 \mu \mathrm{l}$ of $120 \mathrm{mM} \beta \mathrm{ME}$ and $25 \mu \mathrm{l}$ of $120 \mathrm{mM} \mathrm{GSH}$. After incubation for $60 \mathrm{~min}$ at $35{ }^{\circ} \mathrm{C}$, the reaction was terminated by adding $30 \mu \mathrm{l}$ of $50 \%$ sulfosalicylic acid followed by incubation on ice for $5 \mathrm{~min}$. Sulfosalicylic acid was added to the same mixture without incubation $(0 \mathrm{~min})$ to determine the initial PC level (which also represents the in vivo PC level). PCs were analysed on a reverse phase column (Hypersil ODS, $100 \times 2.1 \mathrm{~mm}, 5 \mu \mathrm{m}$, Thermo Scientific) with post-column derivatisation using Ellman reagent, in an Alliance 2690 system equipped with a UV W996 photodiode array detector (Waters, Milford, MA, USA) at $412 \mathrm{~nm}$. The PCs were quantified using a glutathione calibration curve. The specific activity of PCS was calculated using PC produced during the 60-min incubation compared with the initial level and was expressed as nanomoles PC per minute per gram FW.

\section{Polyamine analysis}

After homogenising samples with perchloric acid, the extract was centrifuged at $10,000 \mathrm{~g}$ at $4{ }^{\circ} \mathrm{C}$ for $10 \mathrm{~min}$ and the supernatant was used for the pre-column derivatisation with dansyl chloride (Németh et al. 2002). PUT, spermidine (SPD) and spermine (SPM) were analysed together with 1,3diaminopropane (DAP), the terminal catabolic product of SPD and SPM, by HPLC on a reverse phase Kinetex column $(\mathrm{C} 18,100 \times 2.1 \mathrm{~mm}, 5 \mu \mathrm{m}$, Phenomenex, Inc., CA, USA) using a W2690 separation module and a W474 scanning fluorescence detector with excitation at $340 \mathrm{~nm}$ and emission at $515 \mathrm{~nm}$ (Waters, Milford, MA, USA).

\section{Polyamine oxidase enzyme activity}

The activity of polyamine oxidase (PAO, EC 1.5.3.3.) was estimated spectrophotometrically as described by Takács et al. (2016). Enzyme activity was expressed as nanomoles of $\Delta^{1}$-pyrroline per minute per gram $\mathrm{FW}$ using an extinction coefficient of $1.86 \times 10^{3} \mathrm{~mol}^{-1} \mathrm{~cm}^{-1}$.

\section{Extraction of salicylic acid and abscisic acid: analytical procedure}

Both extraction and ultra-performance liquid chromatography with tandem mass spectrometry (UPLC-MS/MS) were carried out according to Vrhovsek et al. (2012) with slight modifications, described in detail by Pál et al. (2019). Briefly, after extraction with methanol:water $(2: 1)$ to a final sample ratio of $100 \mathrm{mg} \mathrm{FW} / \mathrm{ml}$, the UPLC-MS/MS analysis was performed on a Waters Acquity I class UPLC system coupled to a Waters Xevo TQ-XS (Milford, MA, USA) equipped with a UniSpray ion source (US) operated in timed MRM mode, where argon was used as a collision gas. Separation was achieved on a Waters Acquity HSS T3 column $(1.8 \mu \mathrm{m}, 100 \mathrm{~mm} \times$ $2.1 \mathrm{~mm}$ ), maintained at $40{ }^{\circ} \mathrm{C}$. Water and acetonitrile gradients were used and both mobile phases contained $0.1 \mathrm{v} / \mathrm{v} \%$ formic acid. Data processing was performed using Waters MassLynx 4.2 and TargetLynx software.

\section{Gene expression analysis}

After extracting total RNA from plant tissues using TRI Reagent ${ }^{\circledR}$, the samples were treated with DNase I and cleaned with a Direct-zol ${ }^{\mathrm{TM}}$ RNA MiniPrep Kit (Zymo Research, Irvine, CA, USA). The quality and integrity of RNA was monitored using agarose gel, and the samples were quantified with a Nanodrop 2000 Spectrophotometer (Thermo Fisher Scientific Inc., Wilmington, MA, USA). One thousand nanograms of total RNA was reverse-transcribed using M-MLV Reverse Transcriptase (Promega Corporation, Madison, WI, USA) and oligo(dT)18 (Thermo Fisher Scientific). A CFX96 Touch $^{\text {TM }}$ Real-Time PCR Detection System (Bio-Rad, Hercules, CA, USA) was used for the quantitative real-time PCR reaction, which involved $1 \mu \mathrm{l}$ of 2 -fold diluted cDNA, gene-specific primers (Table 1), housekeeping primer (Ta2291 encoding for an ADP-ribosylation factor described by Paolacci et al. (2009)) and the PCRBIO SyGreen Mix (PCR Biosystems, London, UK). The relative gene expression values were determined with the $2^{-\Delta \Delta \mathrm{Ct}}$ method (Livak and Schmittgen 2001). All the reactions were performed in triplicate using three biological and three technical repetitions.

\section{Statistical analysis}

Data are presented for the most representative repetition of the three independent biological experiments. The results are the means of at least five replicates, and the data were statistically evaluated using the standard deviation and Student's $t$ test methods.

\section{Results}

\section{Effect of cadmium treatment on the biomass parameters, cadmium content and lipid peroxidation}

The biomass parameters (Table 2) showed that 7-day treatment of $50 \mu \mathrm{M} \mathrm{Cd}$ only induced significant changes in the roots, where a decrease was observed in the length and weight in both the WT and Rht3 genotypes. The decrease in shoot length was not significant, but was more pronounced in $\mathrm{Cd}$ - 
Table 1 Gene-specific and housekeeping primers

\begin{tabular}{|c|c|c|c|}
\hline \multirow{2}{*}{$\begin{array}{l}\text { Gene name } \\
\text { Ta2291 } \\
\text { (encoding ADP-ribosylation factor) }\end{array}$} & \multicolumn{2}{|c|}{ Primer sequences $\left(5^{\prime} \rightarrow 3^{\prime}\right)$} & \multirow{2}{*}{$\begin{array}{l}\text { Reference } \\
\text { Paolacci et al. } 2009\end{array}$} \\
\hline & $\begin{array}{l}\text { Forward } \\
\text { Reverse }\end{array}$ & $\begin{array}{l}\text { GCTCTCCAACAACATTGCCAAC } \\
\text { GCTTCTGCCTGTCACATACGC }\end{array}$ & \\
\hline TaNCED & $\begin{array}{l}\text { Forward } \\
\text { Reverse }\end{array}$ & $\begin{array}{l}\text { CCTCGAAGCCCAGCACTAAT } \\
\text { GAGAGCGAGAGGTCCAATGG }\end{array}$ & Gallé et al. 2013 \\
\hline TaP5CS1 & $\begin{array}{l}\text { Forward } \\
\text { Reverse }\end{array}$ & $\begin{array}{l}\text { AGGCTGGGTATGAGAGTGC } \\
\text { TAAGGCATCAGGTCGGGAC }\end{array}$ & Pál et al. 2018b \\
\hline TaPCS1 & $\begin{array}{l}\text { Forward } \\
\text { Reverse }\end{array}$ & $\begin{array}{l}\text { CCTTCAAGCAGACTGGGACT } \\
\text { GAGAAGCGTCAATGGAACCC }\end{array}$ & Tajti et al. 2018 \\
\hline TaOAT & $\begin{array}{l}\text { Forward } \\
\text { Reverse }\end{array}$ & $\begin{array}{l}\text { TGATGATCGCTCGGCTTTACA } \\
\text { CAGTAGCACCCATTGTTGCAG }\end{array}$ & Pál et al. 2018b \\
\hline TaPAO & $\begin{array}{l}\text { Forward } \\
\text { Reverse }\end{array}$ & $\begin{array}{l}\text { GCTCAAAATCAGCCAATTCCA } \\
\text { TTCGCCATTTGTTGAGCTCT }\end{array}$ & Xiong et al. 2017 \\
\hline TaICS & $\begin{array}{l}\text { Forward } \\
\text { Reverse }\end{array}$ & $\begin{array}{l}\text { TTCAGCTCCACCAAACCAACCA } \\
\text { GGTTTGCCCACTGAAGAAGCG }\end{array}$ & Kovács et al. 2014 \\
\hline
\end{tabular}

treated wild genotypes (shoot length was $84.3 \%$ of the control for WT and 93.25\% for Rht3).

Table 3 shows that $\mathrm{Cd}$ treatment resulted in high $\mathrm{Cd}$ accumulation in the roots of both genotypes. $\mathrm{Cd}$ was also translocated into the leaves. The increase in MDA content indicated that the $\mathrm{Cd}$ exposure caused oxidative stress, especially in the leaves. A significantly higher level of lipid peroxidation was detected in WT than in the Rht3 dwarf genotype. The results also indicated that the higher tolerance of the mutant line was not due to limited $\mathrm{Cd}$ absorption or translocation, as higher leaf $\mathrm{Cd}$ content was measured in dwarf plants than of the WT (Table 3 ).

\section{Changes in proline synthesis after cadmium treatment}

Cd stress reduced the amount of proline in the leaves of both genotypes, but to a greater extent in the Rht3 plants (Fig. 1a). In contrast, in the roots, high proline accumulation was observed only in the case of the WT. These changes only partially correlated with the expression levels of the OAT and P5CS genes (Fig. 1b, c). The transcript level of OAT decreased in the leaves and roots of both genotypes after $\mathrm{Cd}$ treatment, while that of P5CS only decreased in the leaves of Cd-treated Rht3 plants and increased in the roots of WT. These results suggested that $O A T$ expression affected the proline content in the leaves, while the P5CS expression pattern correlated with proline levels in the roots, and only partly in the leaves.

\section{Phytochelatin content and phytochelatin synthase activity after cadmium treatment}

Only phytochelatin $3\left(\mathrm{PC}_{3}\right)$ was detected in the leaves in vivo (Fig. 2a), and its amount was not influenced by $\mathrm{Cd}$ treatment. However, 7 days of $50 \mu \mathrm{M} \mathrm{Cd}$ treatment induced the synthesis of PCs in the roots. PCs with $n=2-4$ could be detected in $\mathrm{Cd}-$ treated, wild-type and mutant genotypes (Fig. 2a). The highest accumulation was found for $\mathrm{PC}_{4}$ in Rht 3 plants. The in vitro PCS activity was induced after Cd treatment, especially in the roots, but no profound difference was observed between the two genotypes (Fig. 2b). The PCS expression also increased in the roots of both genotypes (Fig. 2c), but it was downregulated in the leaves of Cd-treated Rht3 plants, probably due to the negative feedback regulation caused by the accumulation of $\mathrm{PC}_{4}$.

Table 2 Effects of 7-day 50- $\mu \mathrm{M} \mathrm{Cd}$ treatment on the biomass parameters of wheat genotypes (wild: WT and dwarf genotypes: Rht3). Data represent mean values $\pm \mathrm{SD}$. Different letters indicate significant differences at $P \leq 0.05$ level

\begin{tabular}{|c|c|c|c|c|c|}
\hline & \multirow[b]{2}{*}{ Treatments } & \multicolumn{2}{|l|}{ Shoot } & \multicolumn{2}{|l|}{ Root } \\
\hline & & WT & Rht3 & WT & Rht3 \\
\hline \multirow[t]{2}{*}{ Length (cm) } & Control & $38.72 \pm 3.29 b$ & $17.44 \pm 2.25 \mathrm{a}$ & $25.5 \pm 0.71 b$ & $21.5 \pm 0.7 \mathrm{a}$ \\
\hline & $50 \mu \mathrm{M} \mathrm{Cd}$ & $35 \pm 3.1 \mathrm{~b}$ & $16.15 \pm 2.75 \mathrm{a}$ & $21.5 \pm 1.12 \mathrm{a}$ & $20.5 \pm 0.8 \mathrm{a}$ \\
\hline \multirow[t]{2}{*}{ Weight (g/plant) } & Control & $0.69 \pm 0.14 b$ & $0.38 \pm 0.09 a$ & $0.82 \pm 0.24 \mathrm{c}$ & $0.43 \pm 0.01 \mathrm{~b}$ \\
\hline & $50 \mu \mathrm{M} \mathrm{Cd}$ & $0.65 \pm 0.12 b$ & $0.35 \pm 0.11 \mathrm{a}$ & $0.42 \pm 0.14 b$ & $0.23 \pm 0.04 \mathrm{a}$ \\
\hline
\end{tabular}


Table 3 Effects of 7-day 50- $\mu \mathrm{M} \mathrm{Cd}$ treatment on the cadmium content and the level of lipid peroxidation (malondialdehyde [MDA] level) in the leaves and roots of wheat genotypes (wild: WT and dwarf genotypes:
Rht3). Data represent mean values $\pm \mathrm{SD}$. Different letters indicate significant differences at $P \leq 0.05$ level

\begin{tabular}{|c|c|c|c|c|c|}
\hline & \multirow[b]{2}{*}{ Treatments } & \multicolumn{2}{|l|}{ Leaves } & \multicolumn{2}{|l|}{ Roots } \\
\hline & & WT & Rht3 & WT & Rht3 \\
\hline \multirow[t]{2}{*}{ Cd content ( $\left.\mu \mathrm{g} \mathrm{g}^{-1} \mathrm{DW}\right)$} & Control & - & - & - & - \\
\hline & $50 \mu \mathrm{M} \mathrm{Cd}$ & $48.5 \pm 4.3 \mathrm{a}$ & $114 \pm 11.8 b$ & $2394 \pm 164 b$ & $1976 \pm 153 \mathrm{a}$ \\
\hline \multirow[t]{2}{*}{ MDA (nmol g $\left.{ }^{-1} \mathrm{FW}\right)$} & Control & $4.1 \pm 0.7 \mathrm{a}$ & $4.5 \pm 0.7 \mathrm{a}$ & $2.3 \pm 0.2 \mathrm{a}$ & $2.4 \pm 0.4 \mathrm{ab}$ \\
\hline & $50 \mu \mathrm{M} \mathrm{Cd}$ & $7.7 \pm 0.5 \mathrm{c}$ & $6.1 \pm 0.2 \mathrm{~b}$ & $3 \pm 0.4 b$ & $3 \pm 0.3 b$ \\
\hline
\end{tabular}

Fig. 1 Effects of 7-day $50-\mu \mathrm{M}$ $\mathrm{Cd}$ treatment on the proline content (a), and on the gene expression levels of ornithine aminotransferase $(O A T: \mathbf{b})$ and $\Delta^{1}$ pyrroline-5-carboxylate synthase (P5CS: c) in the leaves and roots of wheat genotypes (wild: WT and dwarf: Rht3). Data represent mean values $\pm \mathrm{SD}$. Different letters indicate significant differences at the $P \leq 0.05$ level
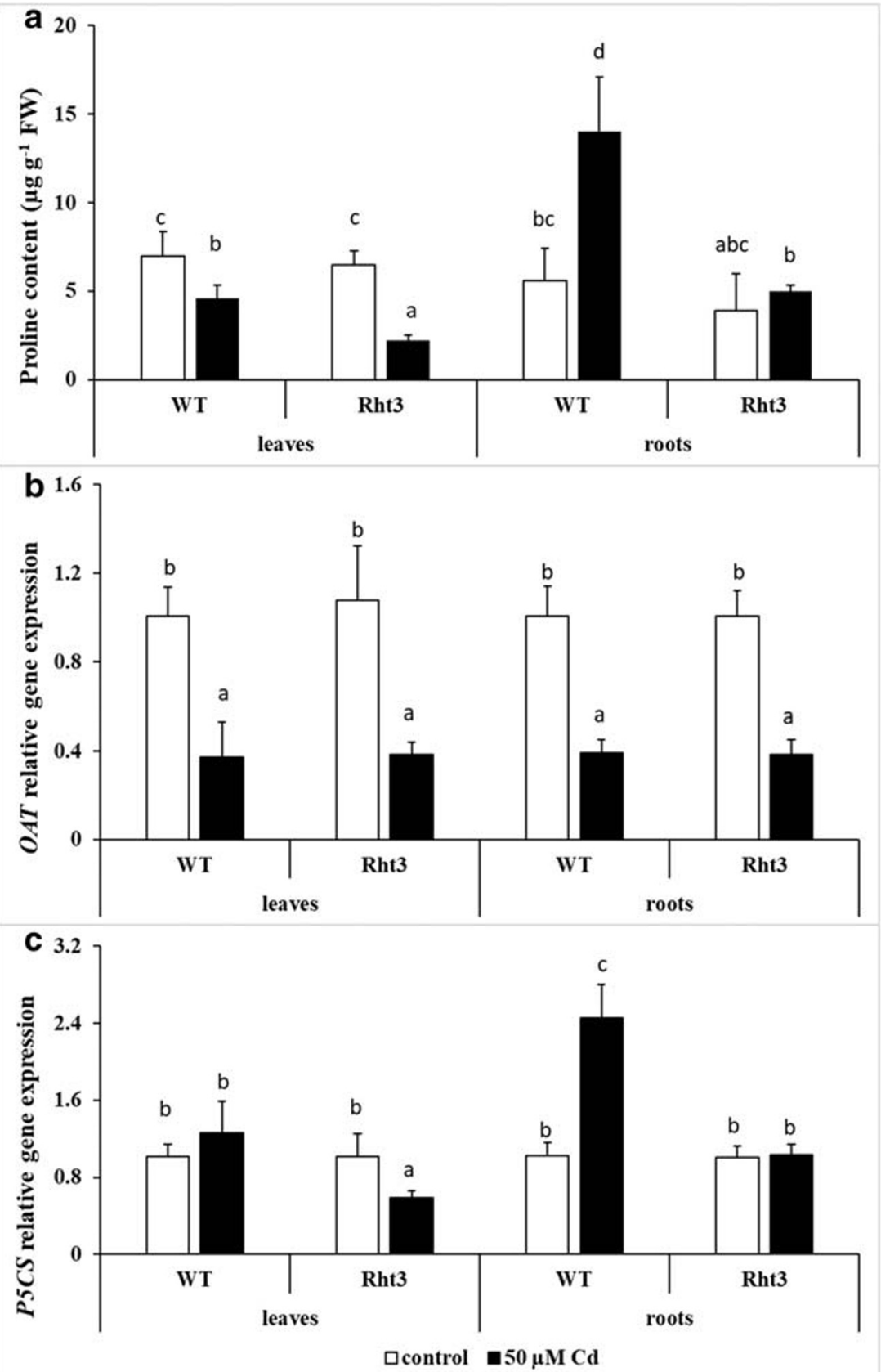


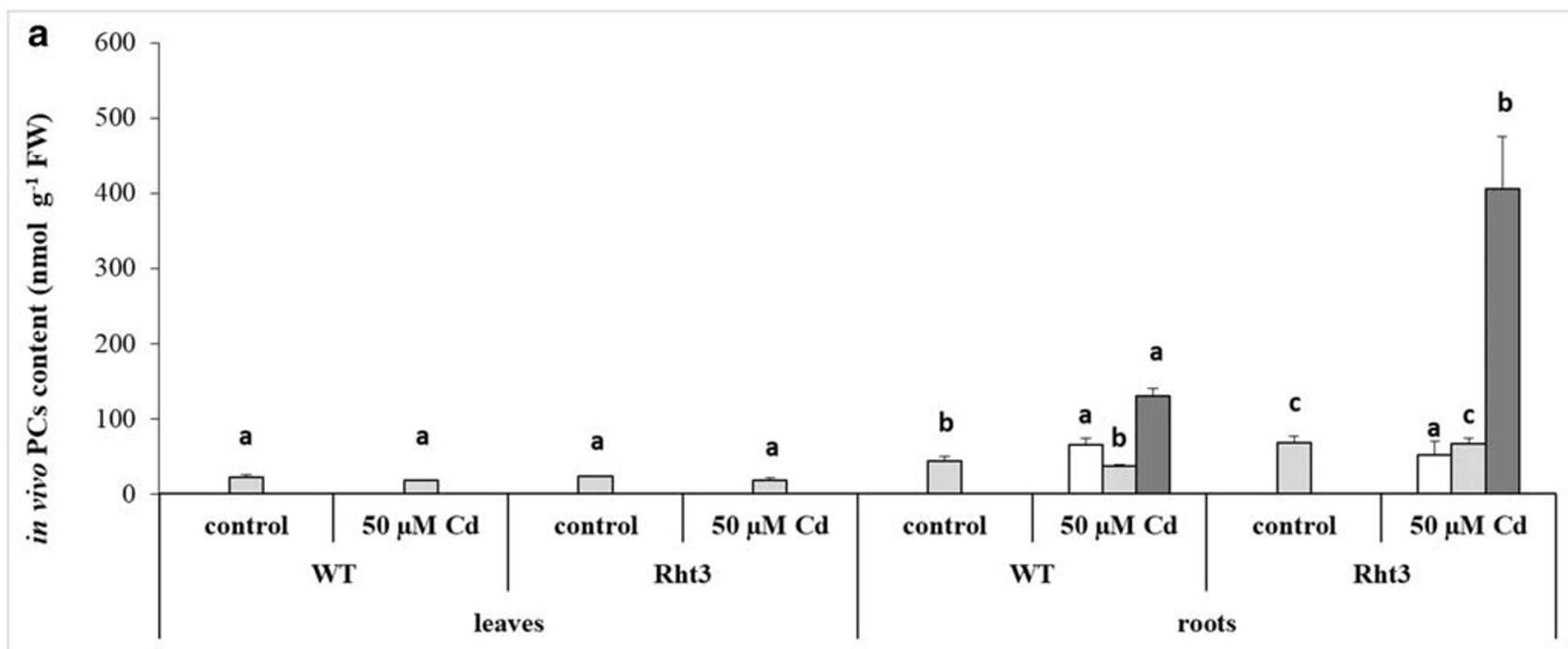

$\square \mathrm{PC2} \square \mathrm{PC} 3 \square \mathrm{PC} 4$

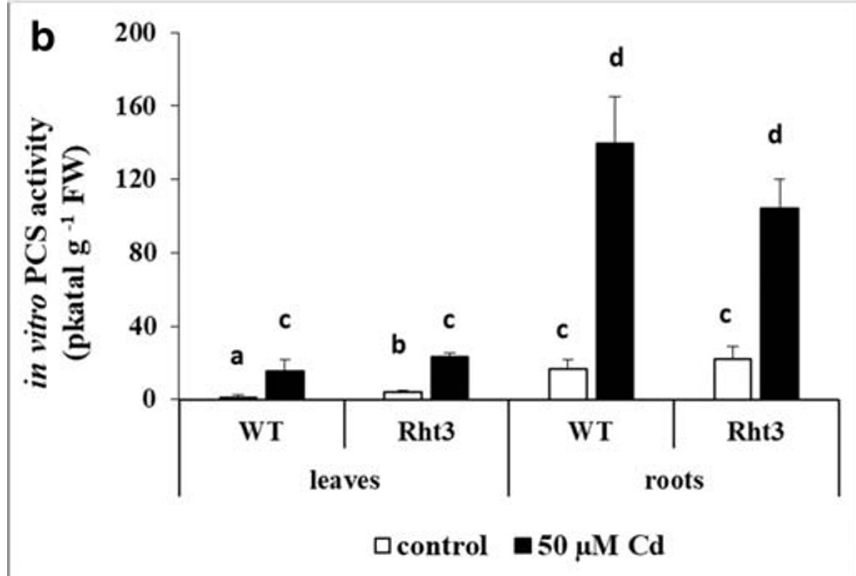

Fig. 2 Effects of 7-day 50- $\mu \mathrm{M} \mathrm{Cd}$ treatment on the in vivo phytochelatin (PC) content (a), in vitro phytochelatin synthase (PCS) activity (b) and gene expression level of phytochelatin synthase (PCS: c) in the leaves and roots of wheat genotypes (wild: WT and dwarf: Rht3). Data represent

\section{Changes in the polyamine metabolism after cadmium treatment}

Pronounced differences in the initial PA contents were observed in the two genotypes tested. The mutant exhibited a lower level of SPD in the leaves, but a higher content of DAP. In the roots, the mutant contained less PUT than the WT plants (Fig. 3a). Cd stress increased the level of PUT in the leaves and roots of both genotypes, with the highest increment in the case of Cd-treated WT roots. A significant increase in the SPD levels was only observed after $\mathrm{Cd}$ stress in the roots, while the quantity of SPM decreased in the leaves of both genotypes. The level of DAP, the catabolic product of SPD and SPM, exhibited slight, but significant increase in the leaves of WT, while decreasing in the Rht3 genotype (Fig. 3a). Parallel with changes in SPD, SPM and DAP, the activity of the PAO enzyme, catalysing the terminal catabolism of SPD and SPM,

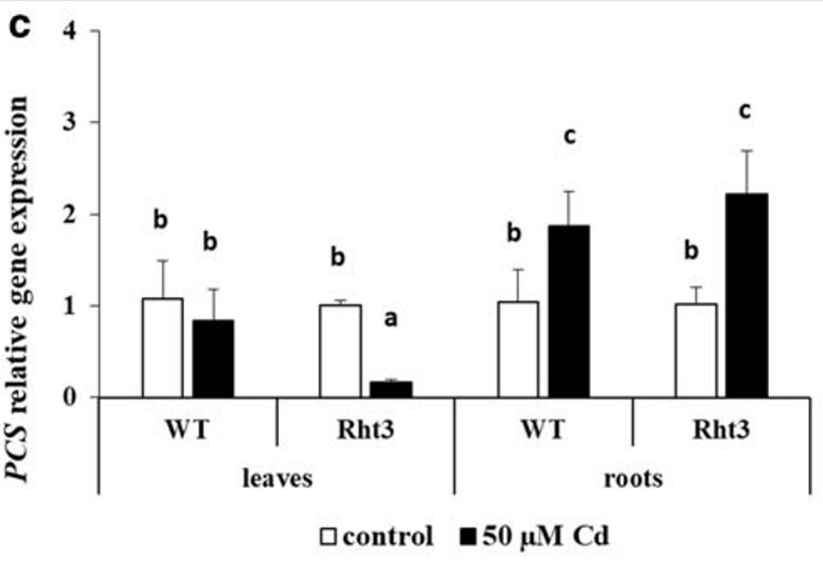

mean values $\pm \mathrm{SD}$. Different letters indicate significant differences between the $\mathrm{PC}_{2}, \mathrm{PC}_{3}$ and $\mathrm{PC}_{4}$ contents, the PCS activity and $P C S$ gene expression level at the $P \leq 0.05$ level

showed no pronounced change. The PAO activity in the leaves was high even under control conditions and was not influenced by $\mathrm{Cd}$ treatment. In the roots, the initial low activity rose only slightly after $\mathrm{Cd}$ stress (Fig. 3b). The expression of the $P A O$ gene was only detected in the leaves, where $\mathrm{Cd}$ treatment increased it dramatically in WT, but not in Rht3 (Fig. 3c).

\section{Effect of cadmium stress on plant hormones, SA and $A B A$}

Cd stress resulted in SA accumulation in the leaves of both genotypes, especially in Rht3, where the basal SA level was also slightly higher (Fig. 4a). Interestingly, the amount of SA did not change in the roots of WT, but decreased slightly in Rht3. The expression of ICS, a gene encoding one of the SA biosynthesis enzymes, was downregulated in the leaves of $\mathrm{Cd}$ - 

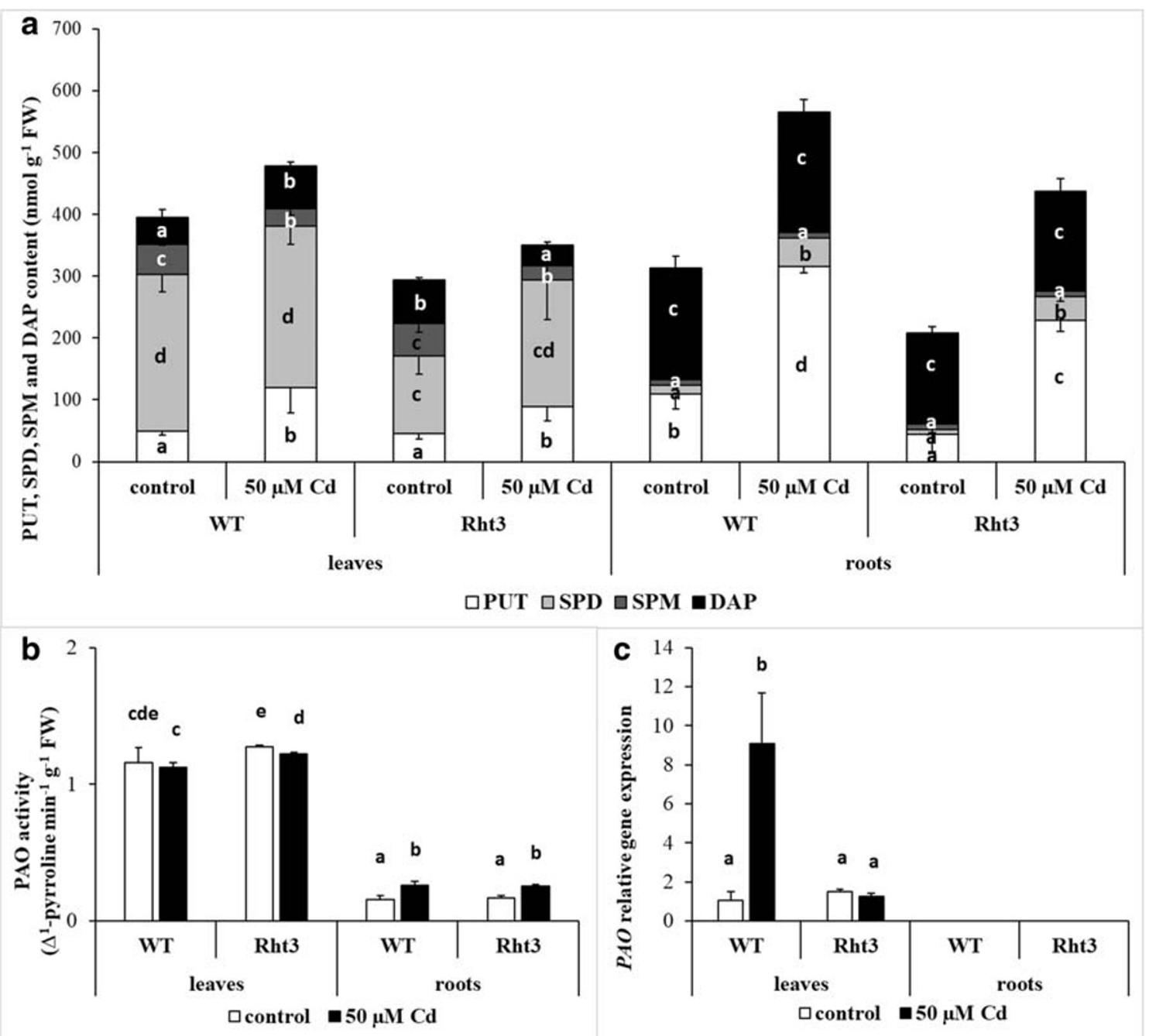

Fig. 3 Effects of 7-day $50-\mu \mathrm{M} \mathrm{Cd}$ treatment on the polyamine content (PUT putrescine, SPD spermidine and SPM spermine) (a), polyamine oxidase (PAO) activity (b) and gene expression level of polyamine

treated plants (Fig. 4b), showed a trend parallel with that of the SA level in the roots.

$\mathrm{Cd}$ treatment also increased the ABA content in the leaves of both genotypes, but to a greater extent in WT (Fig. 5a). The ABA level was much lower in the roots than in the leaves, only increasing slightly after Cd treatment in WT. Although the transcription of NCED, the gene encoding the key enzyme in ABA synthesis, decreased slightly in the leaves of Cdtreated plants, its expression showed a dramatic increase in the roots of Cd-treated WT (Fig. 5b).

\section{Discussion}

It was recently demonstrated that $R h t-B 1 c$ mutation (encoding GA-insensitive DELLA proteins) is responsible for the greater tolerance of wheat plants to Cd stress, which was manifested as better photosynthetic activity (Dobrikova et al. 2017). In oxidase (PAO: $\mathbf{c})$ in the leaves and roots of wheat genotypes (wild: WT and dwarf: Rht3). Data represent mean values \pm SD. Different letters indicate significant differences at the $P \leq 0.05$ level

the present study, further investigations were performed at the molecular level to provide more information on the background of the different levels of $\mathrm{Cd}$ tolerance in the wildtype and mutant lines.

The results confirmed those of Dobrikova et al. (2017), as the Cd-induced root length inhibition was relatively lower observed for the Rht3 genotypes, while the MDA data indicated that the Rht3 line, with repressed GA signalling, had better tolerance of $\mathrm{Cd}$. Changes in the synthesis of proline, PA, PC, ABA and SA were also evaluated to highlight differences between WT and the more Cd-tolerant dwarf genotypes under $\mathrm{Cd}$ stress conditions.

\section{Relationship between proline and PC synthesis}

When Cd enters the cytosol, it activates the synthesis of several metal-binding compounds, such as PC, proline and PA (Chmielowska-Bạk et al. 2014). Cd-induced increases in proline 
Fig. 4 Effects of 7-day $50-\mu \mathrm{M}$ $\mathrm{Cd}$ treatment on the salicylic acid (SA) content (a) and on the gene expression level of isochorismate synthase $(I C S)(\mathbf{b})$ in the leaves and roots of wheat genotypes (wild: WT and dwarf: Rht3). Data represent mean values $\pm \mathrm{SD}$. Different letters indicate significant differences at the $P \leq 0.05$ level

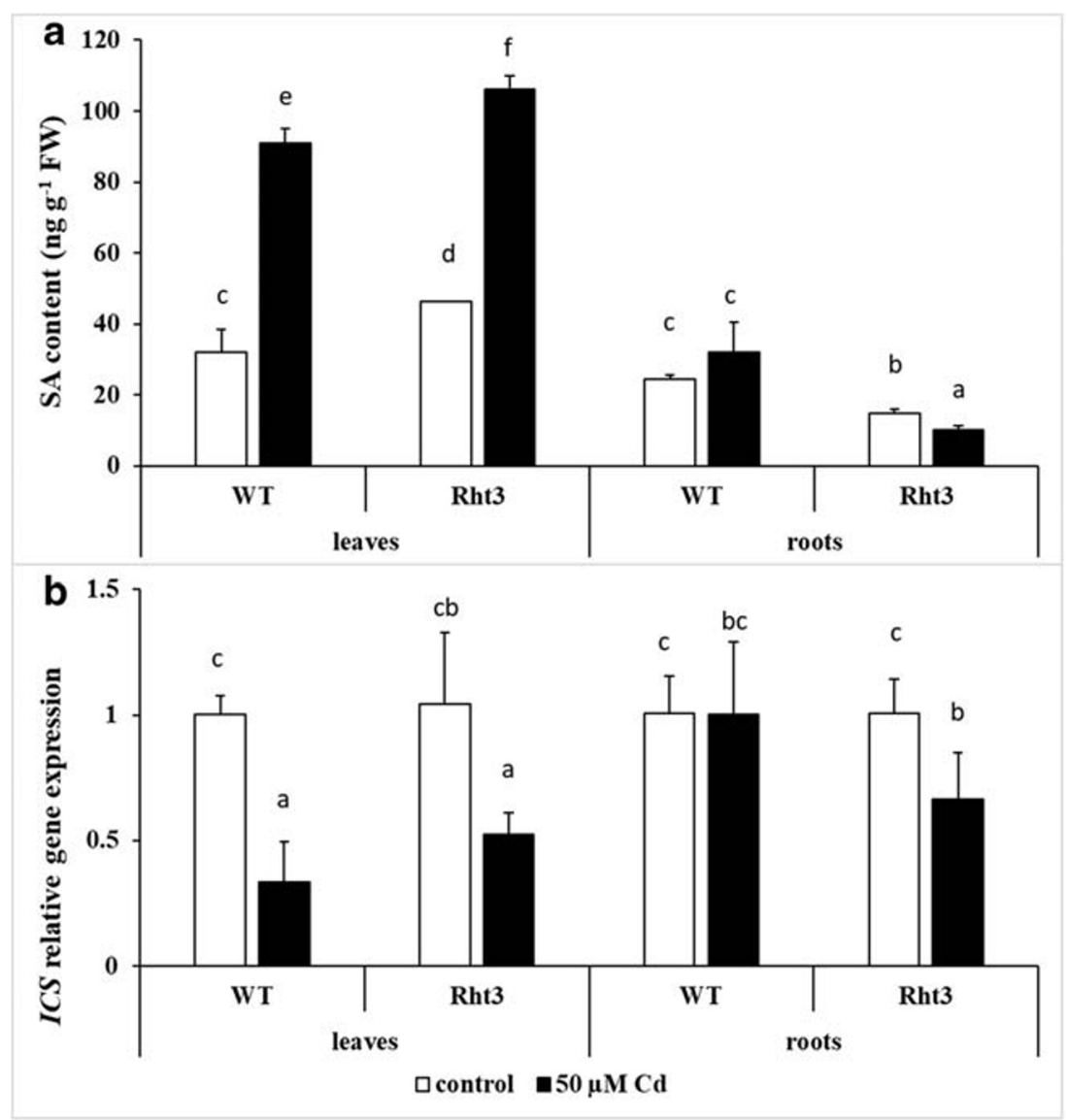

content were reported for a number of plant species (Leskó et al. 2000; Al Khateeb and Al-Qwasemeh 2014). Exogenous proline was also found to protect membrane integrity and reduce ROS production in Solanum nigrum exposed to $\mathrm{Cd}$ stress (Xu et al. 2009). Under the present conditions, Cd stress decreased the proline content in the leaves of both genotypes, but increased it in the roots of WT. In a similar manner, proline accumulation was found to be closely associated with a reduction in root growth in Cd-treated rice roots (Chen and Kao 1995). Proline can be synthesised directly from glutamate in a reaction catalysed by $\Delta^{1}$ pyrroline-5-carboxylate synthetase (P5CS) or from ornithine by ornithine aminotransferase (OAT). However, it is not always clear which pathway is involved in increased proline biosynthesis directly from glutamate by P5CS or from ornithine by OAT under stress conditions (Majumdar et al. 2016). For example, recently, it was found that 1-day ABA treatment induced the gene expression of both enzymes, but 1-day PUT treatment only the P5CS1, while osmotic stress after 5 days did not induced any changes in the transcript level either of these gene, despite the fact that proline accumulation occurred. In addition, it was also revealed that the synthesis pathway of PA and proline is regulated partly independently, despite the common precursor, glutamate (Pál et al. 2018b). Furthermore, it should be also taken into consideration that not only the syntheses of PA and proline are linked but also the PA catabolism has also been shown to be closely related to proline accumulation (Aziz et al. 1998). The present results revealed that differences in the root proline content between the wild and mutant genotypes induced by $\mathrm{Cd}$ could be attributed to the altered expression level of P5CS, and not that of $O A T$. In addition, higher proline accumulation was parallel with the highest total PA level in the roots of the Cd-treated WT plants. However, differences in the proline content alone could not explain the better tolerance of Rht 3 to $\mathrm{Cd}$.

PC synthesis has been demonstrated to be a major metal detoxification mechanism in plants. Basal PCS expression was detected even without heavy metal exposure, but it is strongly activated by metal ions (Zitka et al. 2011; Pál et al. 2018a). In wheat, Cd tolerance could be explained by the fast and profound induction of PC production (Kovács et al. 2014). In the present study, $\mathrm{Cd}$ also induced the formation of PCs in the roots of the two genotypes tested, the greatest accumulation being observed for $\mathrm{PC}_{4}$, which was much higher in the Rht3 mutant. However, no differences could be detected in the in vitro PCS activity or PCS gene expression, which may suggest that the only limiting factor is the availability of the precursor for PC synthesis (cysteine) during competing with PA synthesis. Since PCs play an important role in the detoxification of heavy metals, they may be responsible for the higher Cd tolerance observed for the dwarf line. 
Fig. 5 Effects of 7-day $50-\mu \mathrm{M}$ Cd treatment on the abscisic acid (ABA) content (a) and on the gene expression level of the 9-cisepoxycarotenoid dioxygenase gene $(N C E D)$ (b) in the leaves and roots of wheat genotypes (wild: WT and dwarf: Rht3). Data represent mean values $\pm \mathrm{SD}$. Different letters indicate significant differences at the $P \leq 0.05$ level

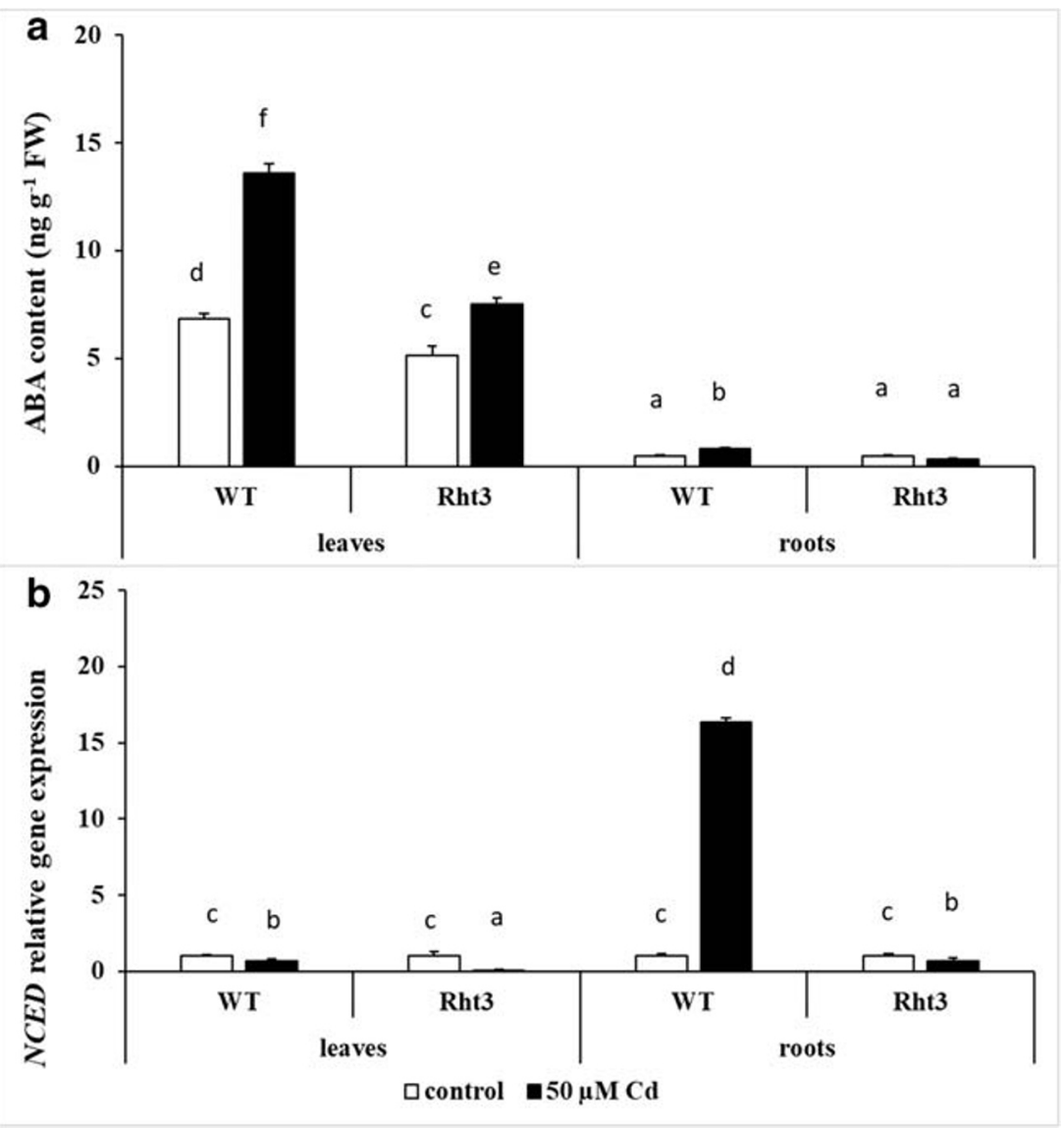

Earlier findings highlighted a possible link between proline synthesis and PC accumulation (Siripornadulsil et al. 2002). Investigations on the green alga Chlamydomonas reinhardtii, a P5CS overexpressor, suggested that the increased proline accumulation during $\mathrm{Cd}$ stress helped to reduce oxidative damage and contributed to a more reducing cellular environment, which may then have led to a higher glutathione level, facilitating PC synthesis (Siripornadulsil et al. 2002). Although proline has been reported to chelate metals (Sharma et al. 1998), the metal-chelating ability of tomato plants was correlated with the gene expression level of $P C S$, but not with that of P5CS or proline content under Cd stress (Kisa 2019). In addition, despite the indirect metabolic connection between the proline and PC synthesis, the $\mathrm{Cd}$ concentration-dependent induction of the PCS expression was accompanied with lower increment in the P5CS transcript level, if any, and a decrease in the proline content (K1sa 2019). Similarly, lower P5CS1 transcription level and lower proline accumulation were found under the present conditions in Rht3 roots, where the highest total PCs level was measured.

\section{Relationship between PA and PC synthesis}

According to the above described connection between proline and PA synthesis, in addition the suggested indirect relationship between the synthesis of proline and PCs, in order to reveal more connections, the PA metabolism was analysed to elucidate the cause of the different levels of Cd tolerance in the wild-type and mutant lines at the molecular level. The synthesis of PAs is related not only to proline (PAs and proline have glutamate as a common precursor) but also in the case of SPD and SPM, with PCs (cysteine is a precursor for the synthesis of both glutathione and S-adenosylmethionine, which is the aminopropyl donor for the synthesis of SPD and SPM), so there seems to be an important metabolic relationship between these protective compounds. Increased contents of PA, especially PUT, and proline have been reported in soybean after $\mathrm{Cd}$ stress, but these did not prevent $\mathrm{Cd}$-induced changes in nitrogen assimilation pathways and the $\mathrm{Cd}$ stress response (Balestrasse et al. 2005). In addition, it has been demonstrated in rice that during $\mathrm{Cd}$ stress, PAs may have a substantial influence on PC synthesis, as exogenous PUT inhibited both the activity and the gene expression level of PCS (Pál et al. 2017). SPD is synthesised from PUT through the addition of an aminopropyl moiety donated by decarboxylated Sadenosylmethionine and catalysed by SPD synthase, while adding an additional aminopropyl moiety to SPD produces SPM with the help of SPM synthase (Liu et al. 2015). SPD and SPM can also be metabolised by FAD-containing polyamine oxidases (PAOs), which can be divided into two 
groups, the first of which catalyses the terminal catabolism of SPD and SPM, and producing DAP in the apoplast, while the second is responsible for peroxisomal back-conversion, from SPM, via SPD, to PUT (Cona et al. 2006; Moschou et al. 2008). According to these, the PA cycle involves the synthesis and the back-conversion of the PAs. In the present experiment, $P A O$ expression could only be detected in the leaves and was only induced in WT after Cd stress. The PAO enzyme activity in the leaves was much higher than in the roots of both genotypes and was not substantially influenced by $\mathrm{Cd}$ stress. Parallel with the changes in leaf DAP, there was no change in the SPD content in WT, but the SPM level decreased, while in Rht3 plants, the SPD level increased and SPM decreased, despite the fact that the PUT content increased in the leaves of both genotypes. These differences suggest that the terminal catabolism of higher PAs was induced in WT, while the interconversion of SPM to SPD and decreased terminal catabolism were responsible for the increment of leaf SPD content in Rht3. These results suggest that the observed cellular PA level was rather due to the controlled PA transport into the apoplast, than the activation of apoplastic PAO activity in the WT under Cd stress. Similarly, in tobacco, increased exodus of newly produced PA into apoplasts was reported under stress conditions (Yoda et al. 2003). This is also in accordance with the changes in the $P A O$ expression, which shows the increasing need for PAO enzyme, and terminal catabolism only in the Cd-treated WT plants, where the highest PA accumulation was found. In the roots, the SPD content increased in both wild-type and mutant plants, in accordance with the increased PUT level, indicating that PA synthesis was induced after $\mathrm{Cd}$ stress. However, the fact that the initial leaf SPD content in WT was double, that in Rht3 plants may be related to the lower inducibility of PC synthesis in the roots under Cd stress, indicating an antagonistic relationship between PCs and higher PAs, because of the common precursor.

PAs were also reported to act as metal chelators (Lomozik et al. 2005). The present results, which showed opposite patterns for PC and PA dynamics, suggest that the tested genotypes used different strategies under cadmium stress conditions, with WT accumulating more proline and PAs, especially PUT, while the dwarf increased $\mathrm{PC}_{4}$ production.

\section{Relationship between proline, PCs, PAs and plant hormones}

The interaction between the compounds analysed (proline, PCs and PAs) and plant hormones (Pál et al. 2015, 2017, 2018a, b) makes the picture even more complex. SA synthesis starts from chorismate, as a precursor, which after, the synthesis pathway is branching to two separated pathways. SA can be synthesised through the phenylalanine ammonia-lyase (PAL) pathway from phenylalanine via benzoic acid, while on the isochorismate pathway, the isochorismate synthsase
(ICS) catalyses isochorismate formation from chorismate. Cd treatment caused concentration-dependent SA accumulation in maize (Pál et al. 2005), and in wheat, SA accumulation was parallel with the increased activity of PAL (Kovács et al. 2014). Under the present conditions, SA accumulation was observed in the leaves of both genotypes, but the ICS expression decreased in the leaves after Cd stress. The latter was probably due to the inhibitory feedback effect of the SA accumulation in the chloroplasts, where ICS catalyse the synthesis of SA.

Although numerous studies have been reported on the positive effect of SA during Cd stress, very few experiments have focused on its effect on PC accumulation. Exogenous SA influenced the PC content and PCS activity in the leaves of maize plants (Gondor et al. 2016), while in barley, it alleviated $\mathrm{Cd}$ toxicity, though the protection was not related to the transcription level of PCS (Metwally et al. 2003). In another study, soaking seeds in SA before $\mathrm{Cd}$ treatment reduced the $\mathrm{Cd}$ induced oxidative stress and influenced the PC composition in maize plants, while at higher $\mathrm{Cd}$ concentrations greater PC accumulation was found compared with plants treated only with Cd (Szalai et al. 2013).

$\mathrm{Cd}$ treatment was also reported to increase the ABA content in potato, in parallel with the upregulation of the PC synthesis, which latter was also induced after ABA treatment (Stroiński et al. 2010). Although studies involving the inhibition of $\mathrm{ABA}$ synthesis indicated that $\mathrm{ABA}$ is required in $\mathrm{Cd}$ signal transduction, $\mathrm{ABA}$ pre-treatment before $\mathrm{Cd}$ stress had negative effect on PC synthesis (Stroiński et al. 2013). In the present study, Cd induced the accumulation of both SA and ABA in the leaves of both wild-type and mutant genotypes, but there were some differences. The accumulation of SA was slightly higher after $\mathrm{Cd}$ exposure in the leaves of the dwarf line, while that of ABA was lower. This is not surprising, as DELLAs are positively affected by ABA (Zentella et al. 2007; $\mathrm{Xu}$ et al. 2014), so their stabilisation may have a negative feedback effect. More and more studies suggest an antagonistic relationship between SA and ABA signalling (de TorresZabala et al. 2007; Meguro and Sato 2015; Manohar et al. 2017), which may explain the lower level of ABA in the dwarf genotype under the present conditions.

These differences in SA and ABA dynamics were only observed in the leaves. In the roots, the SA content tended to decrease while that of ABA did not change in Cd-treated Rht3 plants, but in the WT, Cd exposure greatly increased the expression of NCED. However, in contrast to ICS, NCED gene is not feedback-regulated by the end product, ABA. Indeed, increased ABA content can increase NCED expression. According to these, an important regulatory mechanism of the actual ABA level is it hydroxylation and degradation (Liu et al. 2016).

The higher root $N C E D$ level was parallel with a substantial ABA accumulation in the leaves, accompanied by the intense induction of $P A O$, also in the leaves, and may also be responsible 
for the increased P5CS expression and proline content in the roots of Cd-treated WT. These results agree with finding that ABA influences the synthesis of proline both at the transcriptional level, via the upregulation of $P 5 C S$ expression, and at the posttranscriptional level, by stabilising transcripts of P5CS (Hare et al. 1999), and also confirm the fact that ABA treatment enhances the activity of PAO and the expression of the gene coding for PAO in maize (Xue et al. 2009). In addition, higher ABA content may increase the expression level of the genes involved in PA metabolism (Alcázar et al. 2006). Similarly, ABA application and accumulation resulted in proline accumulation and increased gene expression of P5CS1,OAT and PAO in wheat (Pál et al. 2018b). Our data indicated that there is no direct correlation between changes in PCs and SA or ABA contents in the roots. However, it was found in Sedium alfredii that too high ABA accumulation weakens or even reverses the ABAinduced $\mathrm{Cd}$ stress responsive gene expression ( $\mathrm{Lu}$ et al. 2020), which suggest that although $\mathrm{ABA}$ has regulatory role in $\mathrm{Cd}-$ induced stress responses, higher accumulation of it can shift the metabolic processes into less beneficial direction.

\section{Conclusion}

This is the first study to characterize the relationships between proline, PCs and PAs on the one hand, and the plant hormones $\mathrm{SA}$ and $\mathrm{ABA}$ on the other hand under Cd stress in a GAinsensitive mutant wheat line. The results confirmed that PCs play an important role in the heavy metal detoxification and that this may underlie the higher $\mathrm{Cd}$ tolerance observed in the dwarf line. The results also indicated that $\mathrm{Cd}$ stress induced ABA synthesis in the wild type, which in turn enhanced the proline and PA metabolism. In contrast, the mutant line only exhibited a slight increment in leaf ABA content, which was not sufficient to induce high proline or PUT accumulation in either the leaves or roots, but this was favourable for the synthesis of PCs.

Acknowledgments Open access funding provided by Centre for Agricultural Research

Author contributions G. Sz.: phytochelatin analysis. J. T.: RT-PCR analysis. K. Á. H., R. V. and P. D.: hormone analysis. R. K. and I. D.: plant growth, sample preparation. R. V., S. M. and T. J.: review and editing. M. P.: supervision, analysis of polyamine metabolism, statistical analyses, visualisation and writing.

Funding information This work was financed by grants from the Hungarian National Scientific Research Foundation (KH 124472), the Hungarian-Bulgarian (NKM2018-13) and the Hungarian-Czech bilateral programmes (NKM2018-11), which are gratefully acknowledged.

\section{Compliance with ethical standards}

Conflict of interest The authors declare that they have no conflicts of interest.
Open Access This article is licensed under a Creative Commons Attribution 4.0 International License, which permits use, sharing, adaptation, distribution and reproduction in any medium or format, as long as you give appropriate credit to the original author(s) and the source, provide a link to the Creative Commons licence, and indicate if changes were made. The images or other third party material in this article are included in the article's Creative Commons licence, unless indicated otherwise in a credit line to the material. If material is not included in the article's Creative Commons licence and your intended use is not permitted by statutory regulation or exceeds the permitted use, you will need to obtain permission directly from the copyright holder. To view a copy of this licence, visit http://creativecommons.org/licenses/by/4.0/.

\section{References}

Achard P, Genschik P (2009) Releasing the brakes of plant growth: how GAs shut down DELLA proteins. J Exp Bot 60:1085-1092. https:// doi.org/10.1093/jxb/ern301

Al Khateeb W, Al-Qwasemeh H (2014) Cadmium, copper and zinc toxicity effects on growth, proline content and genetic stability of Solanum nigrum L., a crop wild relative for tomato; comparative study. Physiol Mol Biol Plants 20:31-39. https://doi.org/10.1007/ s12298-013-0211-5

Alcázar R, García-Martínez JL, Cuevas JC, Tiburcio AF, Altabella T (2005) Overexpression of $A D C 2$ in Arabidopsis induces dwarfism and late-flowering through GA deficiency. Plant J 43:425-436. https://doi.org/10.1111/j.1365-313X.2005.02465.x

Alcázar R, Cuevas JC, Patron M, Altabella T, Tiburcio AF (2006) Abscisic acid modulates polyamine metabolism under water stress in Arabidopsis thaliana. Physiol Plant 128:448-455. https://doi.org/ 10.1111/j.1399-3054.2006.00780.x

Alonso-Ramírez A, Rodríguez D, Reyes D, Jiménez JA, Nicolás G, López-Climent M, Gómez-Cadenas A, Nicolás C (2009) Evidence for a role of gibberellins in salicylic acid-modulated early plant responses to abiotic stress in Arabidopsis seeds. Plant Physiol 150: 1335-1344. https://doi.org/10.1104/pp.109.139352

Anton A, Rékási M, Uzinger N, Széplábi G, Makó A (2012) Modelling the potential effects of the Hungarian red mud disaster on soil properties. Water Air Soil Pollut 223:5175-5188. https://doi.org/10. 1007/s11270-012-1269-3

Asgher M, Iqbal M, Khan R, Anjum NA, Khan N (2014) Minimizing toxicity of cadmium in plants-role of plant growth regulators. Protoplasma 252:399-413. https://doi.org/10.1007/s00709-0140710-4

Astolfi S, Zuchi S, Passera C (2004) Role of sulphur availability on cadmium-induced changes of nitrogen and sulphur metabolism in maize (Zea mays L.) leaves. J. Plant Physiol 161:795-802. https:// doi.org/10.1016/j.jplph.2003.11.005

Aziz A, Martin-Tanguy J, Larher F (1998) Stress-induced changes in polyamine and tyramine levels can regulate proline accumulation in tomato leaf discs treated with sodium chloride. Phiol Plant 104: 195-202. https://doi.org/10.1034/j.1399-3054.1998.1040207.x

Balestrasse K, Gallego SM, Benavides MP, Tomaro ML (2005) Polyamines and proline are affected by cadmium stress in nodules and roots of soybean plants. Plant Soil 270:343-353. https://doi.org/ 10.1007/s11104-004-1792-0

Bates LS, Waldren RP, Teare ID (1973) Rapid determination of free proline for water-stress studies. Plant Soil 39:205-207. https://doi. org/10.1007/BF00018060

Chen SL, Kao CH (1995) Glutathione reduces the inhibition of rice seedling root growth caused by cadmium. Plant Growth Regul 16:249252. https://doi.org/10.1007/BF00024781 
Chen J, Zhou J, Goldsbrough PB (1997) Characterization of phytochelatin synthase from tomato. Physiol Plant 101:165-172. https://doi.org/10.1111/j.1399-3054.1997.tb01833.x

Chmielowska-Bąk J, Gzyl J, Rucińska-Sobkowiak R, ArasimowiczJelonek M, Deckert J (2014) The new insights into cadmium sensing. Front Plant Sci 5:245. https://doi.org/10.3389/fpls.2014.00245

Cona A, Rea G, Angelini R, Federico R, Tavladoraki P (2006) Functions of amine oxidases in plant development and defence. Trends Plant Sci 11:80-88. https://doi.org/10.1016/j.tplants.2005.12.009

DalCorso G, Farinati S, Maistri S, Furini A (2008) How plants cope with cadmium: staking all on metabolism and gene expression. J Integr Plant Biol. https://doi.org/10.1111/j.1744-7909.2008.00737.x

de Torres-Zabala M, Truman W, Bennett MH, Lafforgue G, Mansfield JW, Rodriguez Egea P, Bögre L, Grant M (2007) Pseudomonas syringae pv. tomato hijacks the Arabidopsis abscisic acid signalling pathway to cause disease. EMBO J 26:1434-1443. https://doi.org/ 10.1038/sj.emboj. 7601575

Dobrikova AG, Yotsova EK, Börner A, Landjeva SP, Apostolova EL (2017) The wheat mutant DELLA-encoding gene (Rht-B1c) affects plant photosynthetic responses to cadmium stress. Plant Physiol Biochem 114:10-18. https://doi.org/10.1016/j.plaphy.2017.02.015

Flintham JE, Börner A, Worland AJ, Gale MD (1997) Optimizing wheat grain yield: effects of Rht (gibberellin-insensitive) dwarfing genes. J Agr Sci 128(1):11-25. https://doi.org/10.1017/ S0021859696003942

Gallé Á, Csiszár J, Benyó D, Laskay G, Leviczky T, Erdei L, Tari I (2013) Isohydric and anisohydric strategies of wheat genotypes under osmotic stress: biosynthesis and function of ABA in stress responses. J Plant Physiol 170:1389-1399. https://doi.org/10.1016/j.jplph.2013. 04.010

Gallego-Giraldo L, Escamilla-Trevino L, Jackson LA, Dixon RA (2011) Salicylic acid mediates the reduced growth of lignin down-regulated plants. Proc Natl Acad Sci U S A 108:20814-20819. https://doi.org/ 10.1073/pnas.1117873108

Gondor OK, Pál M, Darkó É, Janda T, Szalai G (2016) Salicylic acid and sodium salicylate alleviate cadmium toxicity to different extents in maize (Zea mays L.). PLoS One 11:e0160157. https://doi.org/10. 1371/journal.pone.0160157

Hare PD, Cress WA, Van Staden J (1999) Proline synthesis and degradation: a model system for elucidating stress-related signal transduction. J Exp Bot 50:413-434. https://doi.org/10.1093/jxb/50.333.413

Kisa D (2019) Responses of phytochelatin and proline-related genes expression associated with heavy metal stress in Solanum lycopersicum. Acta Bot Croat 78:9-16. https://doi.org/10.2478/ botcro-2018-0023

Kocheva KV, Landjeva SP, Georgiev GI (2014a) Variation in ion leakage parameters of two wheat genotypes with different $R h t-B 1$ alleles in response to drought. J Biosci 39:753-759. https://doi.org/10.1007/ s12038-014-9471-7

Kocheva K, Nenova V, Karceva T, Petrov P, Georgiev GI, Börner A, Landjeva S (2014b) Changes in water status, membrane stability and antioxidant capacity of wheat seedlings carrying different $R h t$ B1 dwarfing alleles under drought stress. J Agron Crop Sci 200:8391. https://doi.org/10.1111/jac.12047

Kovács V, Gondor OK, Szalai G, Darkó É, Majláth I, Janda T, Pál M (2014) Synthesis and role of salicylic acid in wheat varieties with different levels of cadmium tolerance. J Hazard Mater 280:12-19. https://doi.org/10.1016/j.jhazmat.2014.07.048

Leskó K, Stefanovits-Bányai É, Simon-Sarkadi L (2000) Effect of magnesium on free amino acid and polyamine content in wheat seedling exposed to cadmium stress. Acta biologica Szegediensis, Acta Biol Szeged. Univ

Liu J-H, Wang W, Wu H, Gong X, Moriguchi T (2015) Polyamines function in stress tolerance: from synthesis to regulation. Front Plant Sci 6:827. https://doi.org/10.3389/FPLS.2015.00827
Liu S, Li M, Su L, Ge K, Li L, Li X, Liu X, Li L (2016) Negative feedback regulation of $\mathrm{ABA}$ biosynthesis in peanut (Arachis hypogaea): a transcription factor complex inhibits AhNCED1 expression during water stress. Sci Rep 6:37943. https://doi.org/10. 1038/srep37943

Livak KJ, Schmittgen TD (2001) Analysis of relative gene expression data using real-time quantitative PCR and the $2^{-\Delta \Delta C T}$ method. Methods 25:402-408. https://doi.org/10.1006/meth.2001.1262

Lomozik L, Gasowska A, Bregier-Jarzebowska R, Jastrzab R (2005) Coordination chemistry of polyamines and their interactions in ternary systems including metal ions, nucleosides and nucleotides. Coord Chem Rev. https://doi.org/10.1016/j.ccr.2005.05.002

Lu Q, Chen S, Li Y, Zheng F, He B, Gu M (2020) Exogenous abscisic acid (ABA) promotes cadmium $(\mathrm{Cd})$ accumulation in Sedum alfredii Hance by regulating the expression of $\mathrm{Cd}$ stress response genes. Environ Sci Pollut Res 27:8719-8731. https://doi.org/10.1007/ s11356-019-07512-w

Majumdar R, Barchi B, Turlapati SA, Gagne M, Minocha R, Long S, Minocha SC (2016) Glutamate, ornithine, arginine, proline, and polyamine metabolic interactions: the pathway is regulated at the post-transcriptional level. Front Plant Sci 7:78. https://doi.org/10. 3389/fpls.2016.00078

Manohar M, Wang D, Manosalva PM, Choi HW, Kombrink E, Klessig DF (2017) Members of the abscisic acid co-receptor PP2C protein family mediate salicylic acid-abscisic acid crosstalk. Plant Direct 1: e00020. https://doi.org/10.1002/pld3.20

Meguro A, Sato Y (2015) Salicylic acid antagonizes abscisic acid inhibition of shoot growth and cell cycle progression in rice. Sci Rep 4: 4555-4511. https://doi.org/10.1038/srep04555

Metwally A, Finkemeier I, Georgi M, Dietz K-J (2003) Salicylic acid alleviates the cadmium toxicity in barley seedlings. Plant Physiol 132:272-281. https://doi.org/10.1104/pp.102.018457

Moschou PN, Paschalidis KA, Delis ID, Andriopoulou AH, Lagiotis GD, Yakoumakis DI, Roubelakis-Angelakis KA (2008) Spermidine exodus and oxidation in the apoplast induced by abiotic stress is responsible for $\mathrm{H}_{2} \mathrm{O}_{2}$ signatures that direct tolerance responses in tobacco. Plant Cell 20:1708-1724. https://doi.org/10.1105/tpc.108.059733

Navarro L, Bari R, Achard P, Lisón P, Nemri A, Harberd NP, Jones JDG (2008) DELLAs control plant immune responses by modulating the balance of jasmonic acid and salicylic acid signaling. Curr Biol 18: 650-655. https://doi.org/10.1016/j.cub.2008.03.060

Németh M, Janda T, Horváth E, Páldi E, Szalai G (2002) Exogenous salicylic acid increases polyamine content but may decrease drought tolerance in maize. Plant Sci 162:569-574. https://doi.org/10.1016/ S0168-9452(01)00593-3

Nenova VR, Kocheva KV, Petrov PI, Georgiev GI, Karceva TV, Börner A, Landjeva SP (2014) Wheat Rht-B1 dwarfs exhibit better photosynthetic response to water deficit at seedling stage compared to the wild type. J Agron Crop Sci 200:434-443. https://doi.org/10.1111/ jac. 12090

Pál M, Horváth E, Janda T, Páldi E, Szalai G (2005) Cadmium stimulates the accumulation of salicylic acid and its putative precursors in maize (Zea mays) plants. Physiol Plant 125:356-364. https://doi. org/10.1111/j.1399-3054.2005.00545.x

Pál M, Horváth E, Janda T, Páldi E, Szalai G (2006) Physiological changes and defense mechanisms induced by cadmium stress in maize. J Plant Nutr Soil Sci. https://doi.org/10.1002/jpln.200520573

Pál M, Szalai G, Janda T (2015) Speculation: polyamines are important in abiotic stress signaling. Plant Sci. https://doi.org/10.1016/j.plantsci. 2015.05 .003

Pál M, Csávás G, Szalai G, Oláh T, Khalil R, Yordanova R, Gell G, Birinyi Z, Németh E, Janda T (2017) Polyamines may influence phytochelatin synthesis during Cd stress in rice. J Hazard Mater 340:272-280. https://doi.org/10.1016/j.jhazmat.2017.07.016 
Pál M, Janda T, Szalai G (2018a) Interactions between plant hormones and thiol-related heavy metal chelators. Plant Growth Regul 85: 173-185. https://doi.org/10.1007/s10725-018-0391-7

Pál M, Tajti J, Szalai G, Peeva V, Végh B, Janda T (2018b) Interaction of polyamines, abscisic acid and proline under osmotic stress in the leaves of wheat plants. Sci Rep 8:1-12. https://doi.org/10.1038/ s41598-018-31297-6

Pál M, Ivanovska B, Oláh T, Tajti J, Hamow KÁ, Szalai G, Khalil R, Vanková R, Dobrev P, Misheva SP, Janda T (2019) Role of polyamines in plant growth regulation of $R h t$ wheat mutants. Plant Physiol Biochem 137:189-202. https://doi.org/10.1016/j.plaphy. 2019.02.013

Paolacci AR, Tanzarella OA, Porceddu E, Ciaffi M (2009) Identification and validation of reference genes for quantitative RT-PCR normalization in wheat. BMC Mol Biol 10:11. https://doi.org/10.1186/ 1471-2199-10-11

Sanita di Toppi L, Gabbrielli R (1999) Response to cadmium in higher plants. Environ Exp Bot 41:105-130. https://doi.org/10.1016/ S0098-8472(98)00058-6

Sharma SS, Schat H, Vooijs R (1998) In vitro alleviation of heavy metalinduced enzyme inhibition by proline. Phytochemistry 49:15311535

Siripornadulsil S, Traina S, Verma DPS, Sayre RT (2002) Molecular mechanisms of proline-mediated tolerance to toxic heavy metals in transgenic microalgae. Plant Cell 14:2837-2847. https://doi.org/10. $1105 /$ tpc. 004853

Sofo A, Vitti A, Nuzzaci M, Tataranni G, Scopa A, Vangronsveld J, Remans T, Falasca G, Altamura MM, Degola F, Sanità di Toppi L (2013) Correlation between hormonal homeostasis and morphogenic responses in Arabidopsis thaliana seedlings growing in a $\mathrm{Cd} / \mathrm{Cu} /$ Zn multi-pollution context. Physiol Plant 149:487-498. https://doi. org/10.1111/ppl.12050

Stroiński A, Chadzinikolau T, Gizewska K, Zielezińska M (2010) ABA or cadmium induced phytochelatin synthesis in potato tubers. Biol Plant 54:117-120. https://doi.org/10.1007/s10535-010-0017-z

Stroiński A, Gizewska K, Zielezińska M (2013) Abscisic acid is required in transduction of cadmium signal to potato roots. Biol Plant 57: 121-127. https://doi.org/10.1007/s10535-012-0135-x

Szalai G, Krantev A, Yordanova R, Popova LP, Janda T (2013) Influence of salicylic acid on phytochelatin synthesis in Zea mays during cd stress. Turk J Bot 37:708-714. https://doi.org/10.3906/bot-1210-6

Tajti J, Janda T, Majláth I, Szalai G, Pál M (2018) Comparative study on the effects of putrescine and spermidine pre-treatment on cadmium stress in wheat. Ecotoxicol Environ Saf 148:546-554. https://doi. org/10.1016/j.ecoenv.2017.10.068

Takács Z, Poór P, Tari I (2016) Comparison of polyamine metabolism in tomato plants exposed to different concentrations of salicylic acid under light or dark conditions. Plant Physiol Biochem 108:266-278. https://doi.org/10.1016/j.plaphy.2016.07.020

Thomas JC, Perron M, Davies EC (2004) Genetic responsiveness to copper in the ice plant, Mesembryanthemum crystallinum. Plant
Sci 167:259-266. https://doi.org/10.1016/J.PLANTSCI.2004.03. 022

Tran TA, Popova LP (2013) Functions and toxicity of cadmium in plants: recent advances and future prospects. Turk J Bot. https://doi.org/10. 3906/bot-1112-16

Vrhovsek U, Masuero D, Gasperotti M, Franceschi P, Caputi L, Viola R, Mattivi F (2012) A versatile targeted metabolomics method for the rapid quantification of multiple classes of phenolics in fruits and beverages. J Agric Food Chem 60:8831-8840. https://doi.org/10. 1021/jf2051569

Wen W, Deng Q, Jia H, Wei L, Wei J, Wang H, Yang L, Cao W, Ma Z (2013) Sequence variations of the partially dominant della gene $R h t-$ $B 1 c$ in wheat and their functional impacts. J Exp Bot 64:3299-3312. https://doi.org/10.1093/jxb/ert183

Xiong H, Guo H, Xie Y, Zhao L, Gu J, Zhao S, Li J, Liu L (2017) RNAseq analysis reveals pathways and candidate genes associated with salinity tolerance in a spaceflight-induced wheat mutant. Sci Rep 7(1):2731

Xu J, Yin H, Li X (2009) Protective effects of proline against cadmium toxicity in micropropagated hyperaccumulator, Solanum nigrum L. Plant Cell Rep 28:325-333. https://doi.org/10.1007/s00299-0080643-5

Xu H, Liu Q, Yao T, Fu XD (2014) Shedding light on integrative GA signaling. Curr Opin Plant Biol 21:89-95. https://doi.org/10.1016/j. pbi.2014.06.010

Xue B, Zhang A, Jiang M (2009) Involvement of polyamine oxidase in abscisic acid-induced cytosolic antioxidant defense in leaves of maize. J Integr Plant Biol 51:225-234. https://doi.org/10.1111/j. 1744-7909.2008.00766.x

Yoda H, Yamaguchi Y, Sano H (2003) Induction of hypersensitive cell death by hydrogen peroxide produced through polyamine degradation in tobacco plants. Plant Physiol 132:1973-1981. https://doi.org/ 10.1104/pp.103.024737

Zentella R, Zhang Z-L, Park M, Thomas SG, Endo A, Murase K, Fleet CM, Jikumaru Y, Nambara E, Kamiya Y, Sun T (2007) Global analysis of DELLA direct targets in early gibberellin signaling in Arabidopsis. Plant Cell 19:3037-3057. https://doi.org/10.1105/tpc. 107.054999

Zhu FX, Jiang T, Wang ZW, Lei GJ, Shi YZ, Li GX, Zheng SJ (2012) Gibberellic acid alleviates cadmium toxicity by reducing nitric oxide accumulation and expression of IRT1 in Arabidopsis thaliana. J Hazard Mater 239:302-307. https://doi.org/10.1016/j.jhazmat. 2012.08.077

Zitka O, Krystofova O, Sobrova P, Adam V, Zehnalek J, Beklova M, Kizek R (2011) Phytochelatin synthase activity as a marker of metal pollution. J Hazard Mater 192:794-800. https://doi.org/10.1016/j. jhazmat.2011.05.088

Publisher's note Springer Nature remains neutral with regard to jurisdictional claims in published maps and institutional affiliations. 